\title{
The Role of Administrative Modernization in Shaping Tax Moral to Increase Taxpayer Compliance: Case Study in Madiun, Indonesia*
}

\author{
Received: on March 16th 2020 • Approved: on September 17th 2020 \\ https://doi.org/10.22395/seec.v23n55a10
}

\author{
Moh. Ubaidillah* \\ Nik Amah***
}

\begin{abstract}
The study presented in this paper aimed to find out and obtain empirical evidence about the role of administrative modernization of the tax collector entity in shaping tax morals to improve private individual taxpayer compliance. Sampling in this study used the purposive sampling method, which resulted in a sample of 244 respondents in the city of Madiun (Indonesia). Data analysis was conducted by means of Structural Equation Modeling (SEM) with Partial Least Squares (PLS). The results showed that morals were positively influential towards taxpayer compliance. Furthermore, high morals positively influence the taxpayer's compliance with the modernization of the tax collector administration as moderation variables.
\end{abstract}

\section{KEYWORDS}

Taxpayer compliance; moral; administrative modernization.

\section{JEL CLASSIFICATION}

H2O, H26

\section{CONTENT}

Introduction; 1. Library Overview; 2. Research Methodology; 3. Results of Research and Discussion; 4. Conclusion; References.

\footnotetext{
This article arises from the authors' desire to obtain evidence of the role of administrative modernization in shaping tax morale to improve taxpayer compliance. It is the result of a fundamental research entitled "The role of administrative modernizationin forming tax morals to increase taxpayer compliance". The research was carried out with funding from Research Institutes And Community Dedication of Universitas PGRI Madiun, period 2019

* Bachelor of accounting education, IKIP PGRI Madiun, Madiun, Indonesia. Master of accounting science, Universitas SebelasMaret, Surakarta, Indonesia. Lecturer and researcher in the Faculty of Economics and Business, Universitas PGRI Madiun, Madiun, Indonesia. Member of fundamental research groups. E-mail: mohubaidillah03@gmail.com

-.. Bachelor of economics, Universitas Muhammadiyah Surakarta, Surakarta, Indonesia. Master of accounting science, Universitas SebelasMaret, Surakarta, Indonesia. Lecturer and researcher in the Faculty of Economics and Business, Universitas PGRI Madiun, Madiun, Indonesia. Member of fundamental research groups. E-mail: nikamah@unipma.ac.id
} 


\section{EL PAPEL DE LA MODERNIZACIÓN ADMINISTRATIVA EN LA FORMACIÓN DE LA MORAL FISCAL PARA AUMENTAR EL CUMPLIMIENTO DE LOS CONTRIBUYENTES: ESTUDIO DE CASO EN MADIUN, INDONESIA RESUMEN}

El estudio que se presenta en este trabajo tiene como objetivo buscar y obtener pruebas empíricas sobre el papel de la modernización administrativa de la entidad recaudadora de impuestos en la formación de la moral fiscal para mejorar el cumplimiento de los contribuyentes particulares. En este estudio se utilizó el método de muestreo intencional, que dio como resultado una muestra de 244 encuestados en la ciudad de Madiun (Indonesia). El análisis de los datos se llevó a cabo mediante un modelo de ecuaciones estructurales (SEM) con mínimos cuadrados parciales (PLS). Los resultados mostraron que la moral influye positivamente en el cumplimiento de los contribuyentes. Además, la moral alta influye positivamente en el cumplimiento del contribuyente con la modernización de la administración de los recaudadores de impuestos como variables de moderación.

\section{PALABRAS CLAVE}

Cumplimiento del contribuyente; moral; modernización administrativa.

\section{CLASIFICACIÓN JEL}

$\mathrm{H} 20, \mathrm{H} 26$

\section{CONTENIDO}

Introducción; 1. Visión general de la biblioteca; 2. Metodología de la investigación; 3. Resultados de la investigación y discusión; 4. Conclusión; Referencias.

\section{O PAPEL DA MODERNIZAÇÃO ADMINISTRATIVA NA FORMAÇÃO DA MORAL FISCAL PARA AUMENTAR O CUMPRIMENTO DA LEI DO CONTRIBUINTE: ESTUDO DE CASO EM MADIUN, INDONÉSIA \\ RESUMO}

O estudo apresentado neste documento visava descobrir e obter provas empíricas sobre o papel da modernização administrativa da entidade coletora de impostos na formação da moral fiscal para melhorar o cumprimento das obrigações fiscais dos contribuintes particulares. A amostragem neste estudo utilizou o método de amostragem proposital, que resultou em uma amostra de 244 entrevistados na cidade de Madiun (Indonésia). A análise dos dados foi realizada por meio de Modelagem da Equação Estrutural (SEM) com Quadrados Menos Parciais (PLS). Os resultados mostraram que a moral era positivamente influente para o cumprimento das obrigações do contribuinte. Além disso, a moral elevada influencia positivamente o cumprimento do contribuinte com a modernização da administração do coletor de impostos como variáveis de moderação.

\section{PALAVRAS-CHAVE}

Cumprimento do contribuinte; moral; modernização administrativa.

\section{CLASSIFICAÇÃO JEL}

$$
\text { H2O, H26 }
$$

\section{CONTEÚDO}

Introdução; 1. visão geral da biblioteca; 2. metodologia de pesquisa; 3. resultados da pesquisa e discussão; 4. conclusão; referências. 


\section{INTRODUCTION}

Taxes are a major source of government financing and development. The dynamics of tax changes constantly follow the development of Indonesia's social and economic life and society. Fundamental improvements and changes in all aspects of taxation have been the reason for taxation reform, which is a refinement of taxation policy and tax administration system. In order to support the increase in the tax revenues, the Directorate General of Taxation always makes improvements both in the organizational structure, and in its services. According to the regulation of the Director General of Taxation number PER-12 / PJ / 2013 concerning guidelines for structuring, monitoring and evaluating the directorate general of taxation, it is explained that the Directorate General of Taxes continues to make improvements and refinements, one of them being the improvement of the organizational structure. The main objective of this organizational arrangement is so that the functions mandated by the Taxation Law can be carried out properly.

The Directorate General of Taxation (akin to Colombia's Dirección de Impuestos y Aduanas Nacionales - DIAN) is a bureauworking under the Ministry of Finance, in charge of formulating and implementing technical standardization policies in the field of taxation.

The phenomenon of decreasing tax revenue occurred in Indonesia.Tax revenue is defined as the revenues collected from taxes on income and profits, social security contributions, taxes levied on goods and services, payroll taxes, taxes on the ownership and transfer of property, and other taxes."Total tax revenue, as a percentage of Gross Domestic Product (GDP), indicates the share of a country's output that is collected by the government through taxes" (Organisation for Economic Cooperation and Development - OECD, 2020).

Tax revenue can be reflected in the tax ratio. The former "is a gauge of a nation's tax revenue relative to the size of its economy as measured by Gross Domestic Product (GDP)" (Kagan, 2020).Thus, "tax ratio is calculated using the formula for tax revenue divided by Gross Domestic Product (GDP)" (OECD, 2020).Table 1 shows that tax ratio in Indonesia tends to be low compared to some countries in Southeast Asia.

Table 1.Comparison of tax ratio between Indonesia and other Countries in Southeast Asia

\begin{tabular}{ccccccc}
\hline \multirow{2}{*}{ Country } & \multicolumn{6}{c}{ Years } \\
\cline { 2 - 7 } & 2012 & 2013 & 2014 & 2015 & 2016 & 2017 \\
\hline Indonesia & $11,4 \%$ & $11,3 \%$ & $10,8 \%$ & $10,7 \%$ & $10,3 \%$ & $9,9 \%$ \\
Malaysia & $15,6 \%$ & $15,3 \%$ & $14,8 \%$ & $14,3 \%$ & $13,8 \%$ & $13,1 \%$
\end{tabular}




\begin{tabular}{ccccccc}
\hline \multirow{2}{*}{ Country } & \multicolumn{7}{c}{ Years } \\
\cline { 2 - 7 } & 2012 & 2013 & 2014 & 2015 & 2016 & 2017 \\
\hline Thailand & $15,4 \%$ & $17,3 \%$ & $15,9 \%$ & $16,3 \%$ & $15,4 \%$ & $14,8 \%$ \\
Singapore & $13,9 \%$ & $13,5 \%$ & $13,9 \%$ & $13,6 \%$ & $13,7 \%$ & $14,8 \%$ \\
Vietnam & $19,0 \%$ & $19,1 \%$ & $\mathrm{~N}^{*}$ & $\mathrm{~N}^{*}$ & $\mathrm{~N}^{*}$ & $\mathrm{~N}^{*}$ \\
\hline
\end{tabular}

\section{*Unavailable data.}

\section{Source: World Bank Group, https://data.worldbank.org/indicator/GC.TAX.TOTL.GD.ZS?}

Is the low tax ratio in Indonesia, and its declining trend from 2012 to 2017, a manifestation of the lack of tax compliance, the latter being the level in which a taxpayer meets or fails to meet the prevailing taxation regulations in his or her country? (Pertiwi, 2017). According to Sutedi (2013, p. 227), there are two kinds of obedience:

- Formal obedience: The taxpayer fulfills duty formally pursuant to taxation law.

- Materials obedience: The taxpayer, according to substantial/ truth, fulfills all taxation rules, that is, appropriate contents and taxation law soul.

In addition, the low tax revenue was allegedly due to various tax scandal cases involving unscrupulous individuals (taxpayers, and tax authorities). For several years there have been tax scandals such as fake tax invoices, tax corruption cases, tax mafia, and tax evasion,among others. Examples of tax cases that occur in Indonesia are tax evasion by PT. Asian Agri Group in 2014. The former Asian Agri manager was found guilty of continually submitting false or incomplete tax return (Indonesia: Surat Pemberitahuan) and information ones (Hukumonline.com, 2014). According to Mardiasmo (2019, p. 40), tax return (Indonesia: Surat Pemberitahuan) is a documentation used by the taxpayer to report the calculation or payment of taxes, tax objects or non-tax objects, or assets and liabilities, according to the provisions of taxation laws.

Another example is tax evasion by Google:That companytakes advantage of a tax strategy called "double Irish, Dutch Sandwich", which allows itto avoid US income taxes or to withholdtaxes on profits that are implemented in Europe (CNBC Indonesia, 2019). A series of scandals raise twoquestions:How wasthe tax moral of citizens, andhow was administrative modernization shape tax moral to improve taxpayer compliance.

Tax morale can be defined as the intrinsic motivation to obey and pay taxes so as to contribute voluntarily to the provision of public goods (Torgler and Schneider, 2004, in Cahyonowati, 2011). 
According to Cahyonowati (2011), taxmorale is a key determinant that can explain why people are honest or fraudulent in tax matters. It can be concluded that the taxmoral is a determinant of one's attitude to fulfilltax rights and obligations. In connection with the efforts to increase government tax compliance in particular, the Directorate General of Taxation seeks to issue policies for optimizing tax revenues by investing in modernization of tax administration. The Directorate performs a system update called "e-system" whose utilization is expected to facilitate taxpayers to carry out their tax obligations (especially to pay and report taxes).

The modernization of the tax administration suppressed the original taxation system - Official Assessment System - to prioritize the Self-Assessment System (Pandiangan, 2014, p. 8). The formerwas a tax-voting system that authorizes the Government (Fiskus) to determine the tax amount owed by the taxpayer; while the latter authorizes taxpayers to determine the amount of tax owed (Mardiasmo, 2016, p. 9). According to Widodo et al. (2010, p. 2), on the Self-Assessment System the taxpayer is given the trust to calculate, take into account, deposit, and report and account for the amount of tax owed. Modernization of Indonesian tax administration can be a deterrent factor or, on the contrary, it can create bad tax morale, which in turn will affect tax compliance. According to Feld and Bruno (2002),taxpayers' tax morale is supported, or even raised, when the tax officials treat them with respect. In contrast, when the tax officials consider taxpayers purely as 'subjects' who must be forced to pay their dues, the taxpayers tend to respond by actively trying to avoid taxation.

Various efforts continue to be done by the Government through the Directorate General of Taxation in maximizing tax revenues in Indonesia through the SelfAssessment System. Those reforms, as mentioned by Rahayu and Ita (2009, pp. 120-121), include e-Registration, taxpayer's account, e-payment, e-SPT, e-filling, and e-counseling. The system updates show that the Directorate General of Taxation seeks to continuously optimize the potential of taxes so that the realization of tax revenues can be achieved. System updates also support the role of the Directorate General of Taxation in providing excellent service to taxpayers. Services that provide a variety of convenience and practicality to taxpayers in conducting tax obligations will try to encourage the creation of taxation compliance.

Cahyonowati (2011) has conducted research on tax morale and tax compliance, and built a theoretical model of the factors that affect the level of tax moral.One study by Cahyonowati (2011) has concluded that the level of tax moralein Indonesia has not grown from the intrinsic motivation of the individual, but rather from the compulsion of the tax magnitude — an external factor — . Another study by Feld and 
Bruno (2002) analyzed data for Swiss cantons and five different years from the period 1970 to 1995: These authors established a systematic relationship between external intervention (how the tax officials deal with taxpayers) and intrinsic motivation (individuals' tax morale).

We want to re-examine tax compliance, but with some differences. This research is different from previous ones, which aimed to review the modernization of administration (especially the use of e-system), and its influence on tax compliance. In our study, the modernization of administration as a moderation variable can form a moral tax to improve tax compliance. Thus, the goal of our research was to know the role of administrative modernization in shaping tax moral on compliance with taxpayers. Our study was conducted on individual taxpayers who are registered at the tax service office in the Madiun City, Indonesia. Madiun has great potential because there are individual taxpayers with various professional characteristics.

\section{LIBRARY OVERVIEW}

\subsection{Tax Compliance}

Taxpayer compliance is the fulfillment of tax obligations carried out by the taxpayer in the framework of contributing to the development of the state that is expected to be voluntary. Taxpayer compliance is an important aspect considering the validity of the Self-Assessment System, which grants full authority to the taxpayer to calculate, pay and report its tax obligations (Tiraada, 2013, p. 1002). Widodo et al.(2010, p. 284) stated that taxpayer's compliance is a state where the taxpayer satisfies all tax obligations, and carries out his/hertax rights.

According to Sutedi (2013, p. 227), there are two kinds of obedience, namely formal obedience, and material adherence. The former is a state where taxpayers fulfill formal taxation obligations in accordance with formal provisions in tax laws; while the latter is a condition where the taxpayer is substantive, and, in fact, fulfills all provisions of taxation material, namely according to the content and soul of taxation law. So, it can be concluded that taxpayer compliance is an activity process (fulfillment of tax obligations and obtaining taxation rights by taxpayers), as stipulated in the Taxation Law.

Examination is required to see the taxpayer's compliance. Inspection is a series of activities to collect and process data, information, or evidence conducted objectively and professionally, based on a standard examination to test compliance with tax obligations, or to other purposes in order to implement the provisions of taxation 
legislation (Sumarsan, 2013, p. 93). This tax assessment aims to test the compliance of tax obligations to provide legal capacity, fairness, and guidance to the taxpayer, and to implement the provisions of taxation legislation (Mardiasmo, 2016, pp. 53-54). In Indonesia, implementation of tax audit is governed by regulation of the Minister of Finance No. 123/PMK. 03/2006, conducted by means of field and office inspection.

If the obligation or right of taxation that has been determined is not fulfilled as a form of tax compliance, violations will lead to administrative sanctions. Purwono (2010, p. 68) mentions that sanctions are a real guardrail for the implementation of a rule that matters rights and obligations. The administrative sanctions imposed on the exposure violators include the administrative fines, interest, or tax increases owed. The administrative sanction applies to the violations of taxation administration, which does not lead to tax crimes.

\subsection{Tax Compliance Theory}

Various research projects on taxpayer compliance have been widely undertaken and continue to evolve using various approaches to theory, variables, and research methods (Torgler, 2002). The development of research on tax compliance started from research by Allingham and Sandmo (1972),who applied the theory of Criminological Economics (Economics of Crime). Those authors only included variables that are considered deterrence effect, with their analysis using expected utility theory. Further research by Kahneman and Tversky (1979) is not as important as expected utility theory. These authors argue that theory's expected utility used as an analysis on Allingham and Sandmo (1972) has uncertainty. The intended uncertainty is not to be aware of the potential results of the amount of taxable income hidden taxpayers are influenced by substantial probabilities will be the taxpayer. Kahneman and Tversky (1979) developed a prospect theory as an alternative to the first theory.

Andreoni et al. (1998) are pioneers in developing research on tax compliance by exploring psychological, moral, and social factors. Tax compliance in experimental research by Alm and McKee (1998) includes psychological, moral, and social elements by classifying taxpayer behavior through an internal (moral behavior) approach and a government decision. The internal approach consists of a functional factor that is personal (moral consideration), and a taxpayer motivation posture (taxpayer's mental attitude to the tax authorities and prevailing taxation systems). An external approach relates to the taxpayer's attitude to the government's decision on taxation rules and systems. 
Kirchler et al. (2008), who developed a model with Slippery Slope Theory, explained that the psychological-social and deterrence factor has a positive effect on tax compliance. However, the difference from previous research on the same topic is that psychological social factors are influential in voluntary tax compliance, while deterrence factors (such as tax fines, checks and investigations) affect the imposed tax compliance.

\subsection{Modernization of Taxation Administration}

The application of this modern taxation administration is a positive indication of the Indonesian Government to manage taxes effectively and efficiently in a joint effort with the taxpayer society (Purwono, 2010, p. 18).Widodo et al. (2010, p. 3) explained that the modernization that began to occur in 2002 covered the reform of taxation regulations and service systems, the improvement on human resources' quality, and the organisation's restructuring. The modernization of administration as a form of improvement of the Ministry of Taxation has been implemented to support the creation of tax compliance.

According to the Finance Department of the Republic of Indonesia (2007, p. 16) improvement of business process is also carried out through information and communication technologies(ICTs), with the opening of four e-system facilities: E-registration (System registration, change Data of WP fund or confirmation or revocation of confirmation of PKP through online direct connected system with DJP), E-filing (delivery of SPT online via internet and real time), E-payment (the State acceptance module where the tax payment system conducted online), and E-Counseling (a tax service provided to the taxpayer for online consultation). All these facilities include an e-system application, which is used to support the smooth administration through Internet technology (Pandiangan, 2014). The application is provided to facilitate taxpayers in carrying out their tax obligations without being constrained for 24 hours a day and 7 days a week, including holidays. On our analysis, assessment on the modernization of tax administration is limited to the form of Business Process improvement, and the utilization of the aforementioned ICTs.

\subsection{Tax moral}

In the field of taxation, the moral aspect is very important in improving the taxpayer's compliance because paying tax is not separated from the condition of the taxpayer behavior itself. Individuals who prioritize their orientation to universal values, such as honesty and fairness, will certainly be more obedient than individuals who are less concerned with honesty and justice (Rakhmat, 2007, p. 93). 
According to Ajzen (2002, p. 4),"Moral obligation is defined as the moral derived from each individual who is likely to have no one else". Wanzel (2004) concluded in his research that the taxpayers moral, ethics, and social norms are very influential in their conduct. This author also concluded that taxpayers will behave honestly and adhere to the rules that have been given, so that they have an impact on taxpayer compliance in their tax fulfillment.

\subsection{Hypothesis}

\subsubsection{Tax Moral Effect on Taxpayer Compliance}

Attribution theory explains the process of how the causes and motives of a person's behavior are determined. This theory refers to the way in which a person explains the cause of the behavior of another person, or himself, to be determined whether from internal (such as nature, character, attitude, etc.) or external factors, such as pressure situations or certain circumstances that influence individuals' behavior (Heider, 1958). Attribution theory is closely related to taxpayer compliance with taxes because it concerns someone's behavior. Compliance with taxpayers in accordance with the attribution theory is influenced by internal and external factors, such as services, regulations, and ease of paying taxes. The variables in this study that included internal factors that could influence taxpayer compliance were moral levels.

Moral is very important in improving taxpayer's compliance because payingtaxes is not separated from the condition of the taxpayer behavior itself. This is due to the fact that paying taxes is an activity or deed that must be implemented by someone according to the appropriate applicable regulations. Individuals who prioritize their orientation to universal values, such as honesty and fairness, should, in theory, be more obedient than individuals who are less concerned with them. Wanzel concluded in his research that the moral, ethics, and social norms of taxpayers were very influential in their behavior (Wanzel in Dicka, 2016, p. 19). A concrete hypothesis stems from this description:

- Tax Moral of individual taxpayers positively influence their levels of tax compliance.

\subsubsection{Tax Moral effect on Compliance Taxpayerswith Administrative Modernizationas a Moderation Variable}

Moral is important in tax compliance because itis an attitude that arises in itself whencarrying out rights and obligations. According to Torgler (2007), tax morale asan intrinsic motivation to comply with and pay taxes, so as to voluntarily contribute 
to the provision of public goods and the morals of taxes themselves, is a key to voluntary compliance.

The fact thata person carries out his/her obligation as a rule meansgood morals. Forming good morals needs support from external taxpayers, one of which is services, such as the example of administrative modernization. According to Forest and Sheffrin (2010), taxpayer's compliance can be influenced by several factors, namely the condition of the taxation administration system of a country, services given to the taxpayer, law enforcement taxation, tax check, and tariff applicable taxes. In addition, the simplicity of the taxation system is also important.

In the research conducted by Rahayu and Ita (2009), the modernization of taxation administration system positively and significantly affects taxpayer's compliance. These authors tried to test the administration as a variable of moderation between the moral and taxpayer compliance, so the hypothesis of theirresearch is as follows.

- Administration modernization positively moderates the relationship between tax moral and compliance.

\section{RESEARCH METHODOLOGY}

\subsection{Type of Research}

This research is a quantitative study using primary data from a survey. The data source in this study was obtained from a questionnaire that was distributed to individual taxpayers in the city of Madiun, Indonesia, in 2019.

\subsection{Data Sources and Data Collection Techniques}

The data collection technique of this research was purposive sampling, a non-random sampling technique where the researcher determines the sampling by determining specific characteristics in accordance with the research objectives. There are three criteria for the research sample, including: first, a person who has a Taxpayer Identification Number. Second, individual taxpayers are married. Third, individual taxpayers have paid at least three times. A questionnaire was used for collecting the data.

Ourresearch relied on a basic scale of measurements, using five-scale sequences with the criteria: fully agree $=5$; agree $=4$; neutral $=3$; disagree $=2$; strongly disagree $(\mathrm{STS})=1$. Pilot/pre-testing was conducted before applying the questionnaire to prospective respondents. 


\subsection{Operational definitions and variable measurements}

This research contains three variables: An independent one(tax moral), a dependent one (taxpayer compliance), and one moderator variable (modernization of administrative system).

\subsubsection{Modernization of administrative systems}

Sarunan (2015) explained that the modernization of the taxation administration is aimed atimprovingthe organizational structure and technology utilization in relation to the implementation of the tax administration process. Effectiveness and efficiency of the implementation of the administrative modernization has created a taxpayer's compliance so that, at the end of the research, it can be concluded that the effectiveness and efficiency of modernization of tax administration is tax compliance. For example, at this time, in Indonesia, taxpayers can fill a tax return (SPT) online by using the e-filling facility. This variable was measured by means ofseveral indicators, as it has been done in Zuhair (2018). Researchers coded the questionnaire statement indicator from the administrative system modernization variable to make it easier to read the results of the SmartPLS test. The following is the indicator code for the questionnaire statement: MSA27, MSA28, MSA29, MSA30 and MSA31.

\subsubsection{Taxpayer compliance}

The taxpayer's compliance means his/her adherence to the teaching in taxation. Tax compliance is obedience, submission, obedience, and compliancewith tax regulations. The measurement of the taxpayer compliance variable was adopted in the research of Najla Ulfah Salsabila (2018) with indicators of the timeliness of paying taxes, the timeliness of submitting the SPT, and correct charging of the SPT form. Researchers coded the questionnaire statement indicator from the taxpayer compliance variable to make it easier to read the results of the SmartPLS test. The following is the indicator code for the questionnaire statement: KWP1, KWP2, KWP3, KWP4, KWP4, KWP5, KWP6, and KWP7.

\subsubsection{Tax Moral}

Moral is the individual norm possessed by a person in carrying out his/her exposure. Ethics, principles of life, and feelings of guilt are later attributed to the fulfillment of tax obligations, in this case, for the taxpayer's compliance of the private person. The variable measurement of moral was adopted from Nabilla (2018). This variable uses indicators of violating existing ethics, feelings of guilt if the taxpayer does not 
fulfill their obligations, and life principles regarding taxes. Researchers coded the questionnaire statement indicator from the moral variable to make the results of the SmartPLS test easier to read. The following is the indicator code for the questionnaire statement: MRL8, MRL9, MRL10, MRL11, MRL12, MRL13, MRL14, MRL15, MRL16, MRL17, MRL18, MRL19, MRL20, MRL21, MRL22, MRL23, MRL24, MRL25, and MRL26.

\subsection{Data Analysis Techniques}

In this study, the data analysis was conducted by using Partial Least Square (PLS) approach. PLS is a component-based Structural Equation Modeling (SEM) equation model. According to Ghozali (2006), PLS is an alternative approach that shifts from a covariance-based SEM approach to a variance-based one.

According to Ghozali (2006), the goal of PLS is to help researchers for the purpose of predictions. The formalized model defines the latent variable as a linear aggregate of its indicator. The weight estimation for making the latent variable score component is obtained based on how the inner model and the outer model are specified. The result is the residual variance of the dependent variable.

Evaluation of the outer model was done to assess the validity and reliability of the model. Validity measured with an exploratory average variance (AVE) should be more than 0.5. Furthermore, Reliabilities measured with Cronbach's Alpha should be greater than 0.6 .

By evaluating the inner model, it can be seen whether the value of R-square, used to describe the influence of a specific exogenous latent variable to the endogenous latent variable, has a substantive effect. R-square values of $0.75,0.50$ and 0.25 can lead to conclude that the model is strong, moderate, and weak, respectively.

Standardized Root Mean Square Residual (SRMR) is used to measure the extent to which the model proposed by the researcher is truly fit or not. This is to measure the difference between the observed correlation matrix and the correlation matrix implied in the model. In other words, the SRMR reflects the average magnitude of the difference: The lower SRMR, the better. By convention, the model is appropriate if the SRMR is less than 0.08 (Hu E Bentler, in Garson, 2016, p. 68).

\section{RESULTS AND DISCUSSION}

The following is a description of sample characteristics and the results of the analysis using questionnaire data using SmartPLS tool. 
The Role of Administrative Modernization in Shaping Tax Moral to Increase Taxpayer Compliance: Case Study in Madiun, Indonesia

\subsection{Respondent details}

Table 2 summarizes the details of the respondents by gender and education level. Males count as much as 172 and females 72 . Education level that many respondents education S1 as much as 100 and at least so respondents in the level of education S3 as much as 6.

Table 2. Respondent Details*

\begin{tabular}{ccccccc}
\hline \multirow{2}{*}{ Gender } & \multicolumn{6}{c}{ Education } \\
\cline { 2 - 5 } & SMP & SMA & S1 & S2 & S3 & Total \\
\hline Male & 20 & 47 & 70 & 30 & 5 & 172 \\
Women & 4 & 27 & 30 & 10 & 1 & 72 \\
Total & 24 & 74 & 100 & 40 & 6 & 244 \\
\hline
\end{tabular}

*SMP= Junior High School; SMA= Senior High School; S1= Bachelor's degree; S2= Master's degree; S3= PhD.

Source: Ubaidillah and Amah (2019).

\subsection{Questionnaire Data Results}

The outer model is a stage to determine the validity and reliability. In order to determine the validity of what wasmeasured, an outer loading and AVE were used. The requirement to qualify for validity had to be above 0,50 . The results of the outer loading are 11 indicators that do not meet the criteria because the below 0.50 are KWP2, KWP4, MRL9, MRL17, MRL18, MRL19, MRL20, MRL21, MRL25, MRL26, and MSA29.

Table 3. AVE and Cronbach's Alpha

\begin{tabular}{ccc}
\hline & AVE & Cronbach's Alpha \\
\hline KWP & 0,629919 & 0,870342 \\
MRL & 0,56121 & 0,868262 \\
MSA & 0,800961 & 0,918075 \\
\hline
\end{tabular}

Source: Data Processing result SmartPLS 2 (2019)

The validity measurements in table 3 are AVE results, indicating that the test results of all the construction already meet the criteria $(>0.50)$; while the reliability measurement using Cronbach's Alpha in table 3 indicates that the results of the Cronbach's Alpha test already meet the criteria $(>0.7)$. The results of the validity 
test and reliability have indicated that the research questionnaire data is both valid and reliable.

The inner model was evaluated using R-square $\left(\mathrm{R}^{2}\right)$ for the dependent construct, the T-Test, and a significant part of the structural path parameter coefficient. $\mathrm{R}^{2}$ can be used to assess whether the influence of the independent latent variable has a substantive effect against the dependent latent one.

The PLS test results show that the R-Square value of 0.723528 is included in the strong category, because a value higher than 0.50 indicates that the dependent variable has a substantive effect. Based on the results of calculating SmartPLS, it can be seen to what extent this research model is truly fit or not, which can be seen from the estimated SRMR model, as presented in the table below.

Table 4. Model Fit

\begin{tabular}{ccc}
\hline & Saturated Model & Estimated Model \\
\hline SRMR & 0.077 & 0.077 \\
d_ULS & 1.312 & 1.312 \\
d_G & 2.943 & 2.943 \\
Chi-square & 743.763 & 743.763 \\
NFI & 0.797 & 0.797 \\
\hline
\end{tabular}

Source: Data Processing result SmartPLS (2019).

Based on the SmartPLS calculation results, the SRMR results for the reflective research model were 0.077 Because they were below 0.8 , the research model is included in the good fit category. Hypothesis testing in this study using Path Coefficients (Mean, STDEV, T-Values) is presented by the following test Path Coefficients results.

Table 5. Path coefficients (Mean, STDEV, T-Values)

\begin{tabular}{lccccc}
\hline & $\begin{array}{c}\text { Original } \\
\text { Sample }(\mathrm{O})\end{array}$ & $\begin{array}{c}\text { Sample } \\
\text { Mean }(\mathrm{M})\end{array}$ & $\begin{array}{c}\text { Standard Deviation } \\
(\mathrm{STDEV})\end{array}$ & $\begin{array}{c}\text { Standard Error } \\
(\mathrm{STERR})\end{array}$ & $\begin{array}{c}\text { TStatistics } \\
(|\mathrm{O} / \mathrm{STERR}|)\end{array}$ \\
\hline $\mathrm{MRL}>>$ KWP & 1.35597 & 1.32246 & 0.35473 & 0.35473 & 2.822537 \\
$\mathrm{MRL} * \mathrm{MSA}>>$ KWP & 1.02265 & 0.97306 & 0.74875 & 0.74875 & 3.365803 \\
$\mathrm{MSA}>>$ KWP & 0.77736 & 0.74129 & 0.58462 & 0.58462 & 3.329697 \\
\hline
\end{tabular}

Source: Data Processing result SmartPLS 2 (2019). 
In table 5, it can be seen that moral (MRL) positively affects the tax compliance (KWP), with the T-Statistics value of 2.822537 (above 1.96), and Original Sample of 1.35597 showing positive numbers. Path Coefficients test results show that moral (MRL) positively affects the tax compliance (KWP) with the modernization of administration (MSA), as variable moderation due to the T-Statistics amounts to 6.796691 (above 1.96 )andoriginal sample amounts to 0.74285 , both showing positive numbers.

\subsection{Discussion}

The first hypotheses test results show that moral positively affects taxpayer compliance for the case of Madiun, Indonesia. Tax compliance is inherent in the moral value of taxes, for morals are the attitude and stance of this individual more touching on the part of an individual's sense of duty. It can be seen as a moral obligation to pay taxes, i. e. confidence to contribute to society by paying taxes. When people have good morals, they obey the established tax laws.In this sense, building good morals for future generations must involveapplying character education in schools. According to Santrock, the latter is an education with a personal approach, directly aimed at students; its function is to instill moral values, and also to provide lessons to students about moral knowledge so that theydo not take actions against the prevailing norms.

The second hypothesis test result indicates that moral positively affects the taxpayer's compliance with the modernization of the administration as a moderation variable. Positive influence suggests that the emergence of good moral is enhanced by the administrative modernization of the collecting agency. If the modernization of tax administration is implemented properly, personal taxpayers will be more obedient in reporting their taxes because, with the modernization of tax administration, namely with a good organizational structure, the use of information technology, the improvement of resources and the implementation of good governance, it shall be easier for taxpayers to report their taxes. The higher the modernization of the administration is, a good moral will arise and a sense of responsibility to the taxpayer will be carried out.

\section{CONCLUSION}

From the discussion above, it can be concluded from this study that morale has a positive effect on tax compliance, with modernization as a moderating variable.

Evaluation of the research conducted should consider the limitations that may affect the results of the study. The limitation in this study was the difficulty of controlling the full answer given by the taxpayer. 
It is expected that this research can contribute to improve scholars' understanding of the role of administrative modernization in shaping tax moral to increase taxpayer compliance. The results of this research are also expected to result in a discussion that can be further developed and tested again on other research projects. In addition, this study is expected to be able to contribute to the government so that tax administration is easier to access (and in addition to the government, community leaders provide knowledge and understanding of taxpayers).Subsequent studies are expected to expand the research object to more than one city, and add independent variables. Furthermore, the next method of study should bea mixture one, i. e. a method that combines quantitative and qualitative analysis.

\section{REFERENCES}

Ajzen, I. (2002). Perceived behavioral control, self-efficacy, locus of control, and the theory of planned behavior. Organizational Behavior and Human Decission Processes 50,179-211. https://doi. org/10.1111/j.1559-1816.2002.tb00236.x

Allingham, M.E Sandmo, D. (1972).Income tax evasion: a theoreticalanalysis. Journal ofPublic Economics,1(3), 323-338.https://doi.org/10.1016/0047-2727(72)90010-2

Alm, J. \& McKee, M. (1998). Extending the lessons of laboratory experiments on tax compliance to managerial and decision economics.Managerial and Economics Decision, 19, 259-275. https:// doi.org/10.1002/(SICI) 1099-1468(199806/08)19:4/5<259::AID-MDE890>3.0.CO;2-2

Andreoni, J., Erard, B.,E Feinstein, D. (1998).Tax compliance. Journal of EconomicLiterature, 36 (2), 818-860. https://doi.org/10.1007/978-3-8349-8282-7_12

Arikunto, S. (2006). Prosedur penelitian suatu pendekatan praktek (Revised Edition). Rineka Cipta.

Cahyonowati, N. (2011). Model moral dan kepatuhanperpajakan: wajibpajak orang pribadi. JAAI, 15 (2), 61-177. https://journal.uii.ac.id/JAAI/article/viewile/3749/3326.

CNBC Indonesia (2019, January 4th). Dokumen: Google Lakukan Penghindaran Pajak Rp 327 Triliun. https:/www.cnbcindonesia.com/news/20190104214635-4-49236/dokumen-google-lakukan-penghindaran-pajak-rp-327-triliun.

Feld, L. E Frey, B. (2002). Deterrence and Tax Morale: How Tax Administrations and Taxpayers Interact. OECD Jan Francke Tax Research Award.

Forest, A. ESheffrin, S. (2002). Complexity and compliance: an empirical investigation. National Tax Journal, LV(19). DOI: 10.17310/ntj.2002.1.05.

Garson, G. (2016). Partial Least Squares Regression and Structural Equation Models. Statistical Publishing Associates.

Ghozali, I. (2006). Structural equation modeling, metode alternatif dengan partial least square. Badan Penerbit Universitas Diponegoro.

Ghozali, I. (2012). Partial least squares. Konsep, teknik dan aplikasi. SmartPLS 2.0 M3. Badan Penerbit Universitas Diponegoro. 
Heider, F. (1958). The Psychology of Interpersonal Relations. Wiley.

Hukumonline.com (2014). Kejagung Ultimatum Asian Agri. https://www.hukumonline.com/berita/ baca/lt52ce554e7577a/kejagung-ultimatum-asian-agri/.

Kagan, J. (2020) What Is the Tax-to-GDP Ratio? Investopedia. https://www.investopedia.com/terms/t/ tax-to-gdp-ratio.asp.

Kahneman, D. ETversky, A. (1979). Prospect theory: an analysis of decision under risk. Ekonometrika, 47,263-291.DOI: 10.1142/9789814417358_0006.

Kirchler, E.,Hoelzl, E.,E Wahl, I.(2008).Enforced versus voluntary taxcompliance: the 'slippery slope'framework. Journal of EconomicPsychology, 29(2), 210-225.DOI: 10.1016/j.joep.2007.05.004.

Mardiasmo (2016). Akuntansi sektor publik. Penerbit ANDI.

Nabilla, Z. (2018). Pengaruh kewajiban moral dan lingkungan sosial terhadap kepatuhan wajib pajak orang pribadi pengusaha pada Kantor Pelayanan Pajak Pratama Bantul. In Essay. Economic Faculty - Universitas Negeri Yogyakarta.

Organisation for Economic Cooperation and Development - OECD (2020). Tax revenue (indicator). DOI: $10.1787 / \mathrm{d} 98 \mathrm{~b} 8 \mathrm{cf} 5$-en.

Pandiangan, L. (2014). Administrasi perpajakan, pedoman praktis bagiwajibpajak di Indonesia. Penerbit Erlangga.

Pertiwi, I. (2017). Moral pajak: sebuahopsipeningkatankepatuhanpajakmasyarakatmuslim. Jurnal Al Qardh, V(1). DOI: 10.23971/jaq.v2il.823.

Purwono, H. (2010). Dasar-dasar perpajakan dan akuntansi pajak. Erlangga.

Rahayu, Sri E Salsalina, I. (2009). Pengaruh modernisasi sistem administrasi perpajakan terhadap kepatuhan wajib pajak (Survei atas wajib pajak badan pada KPP Pratama Bandung "X"). Jurnal Akuntansi, 1(2).DOI: 10.28932/jam.vli2.375.

Rakhmat, J. (2007). Psikologi komunikasi. Remaja Rosdakarya.

Salsabila, N. (2018). Pengaruh religiusitas, nasionalisme, kepercayaan pada otoritas, dan tax amnesty terhadap kepatuhan wajib pajak orang pribadi (Studi Empiris Pada Kantor Pelayanan Pajak Pratama Surakarta). InEssay. Economic Faculty - Universitas Islam Indonesia.

Santrock, J. (2007). Perkembangan Anak: EdisiKetujuhJilidDua. Jakarta: PT. Erlangga.

Sarunan, W. (2015). Pengaruh Modernisasi Sistem Administrasif PerpajakanTerhadap Kepatuhan Wajib Pajak Orang Pribadi dan Wajib Pajak Badan pada Kantor Pelayanan Pajak Pratama Manado. Jurnal EMBA,3(4), 518-526.

Sutedi, A. (2013). Hukum pajak. Sinar Grafika.

The Finance Department of the Republic of Indonesia (2007). Modernisasi administrasi perpajakan. Directorate General of Taxes.

The Finance Department of the Republic of Indonesia (2013). The regulation of the Director General of Taxation number PER-12 / PJ / 2013 concerning guidelines for structuring, monitoring and evaluating the directorate general of taxation.The Finance Department of the Republic of Indonesia. 
Tiraada, T. (2013). Kesadaranperpajakan, sanksipajak, sikapfiskusterhadapkepatuhan WPOP di kabupatenMinahasa Selatan. Jurnal EMBA, 1 (3), 999-1008. DOI: 10.35794/emba.v1i3.2305.

Torgler, B. (2002). Speaking to theorists and searching for facts: tax morale and tax compliance in experiments. Journal of Economic Surveys, 16 (5), 657-683. DOI: 10.1111/1467-6419.00185.

Torgler, B. (2007). Tax Compliance and Tax Morale: A Theoretical and Empirical Analysis. Cheltenham. Edward Elgar.

Wenzel, M. 2004. An analysis of norm processes in tax compliance. Journal of Economic Psychology,25,213-228. DOI: 10.1016/S0167-4870(02)00168-X.

Widodo, W., Dedy,EEka, A. (2010). Moralitas,Budaya, dan Kepatuhan Pajak. Alfabeta.

World Bank Group. Accessed from https://data.worldbank.org/indicator/GC.TAX.TOTL.GD.ZS?

Zuhair (2018). Pengaruh modernisasi sistem administrasi perpajakan, sosialisasi pajak, kualitas pelayanan, dan pengetahuan mengenai pajak terhadap kepatuhan wajib pajak (Studi pada wajib pajak restoran di kota Solo dan Yogyakarta). InEssay. Economic Faculty - Universitas Islam Indonesia. 